\title{
Scientists and Scientific Thinking: Understanding Scientific Thinking Through an Investigation of Scientists Views About Superstitions and Religious Beliefs
}

\author{
Richard K. Coll and Mark C. Lay \\ University of Waikato, Hamilton, NEW ZEALAND \\ Neil Taylor \\ University of New England, Armidale, AUSTRALIA
}

Received 25 February 2008; accepted 19 April 2008

\begin{abstract}
Scientific literacy is explored in this paper which describes two studies that seek to understand a particular feature of the nature of science; namely scientists' habits of mind. The research investigated scientists' views of scientific evidence and how scientists judge evidence claims. The first study is concerned with scientists' views of what constitutes superstitious beliefs. The second concerned potential conflicts between scientific theories and evidence, and religious beliefs. The research findings suggest that these scientists, unlike their stereotype, hold idiosyncratic views of what constitutes good scientific evidence and sound, credible testimony. The interviews provide a window into scientific thinking as practiced by modern scientists, and suggest that the scientists are rather more open to alternative thinking than might be supposed. The implications of these findings are discussed in the context of their implications for scientific literacy.
\end{abstract}

Keywords: Literacy, Religion, Science, Sociocultural, Superstition

\section{SCIENCE AND SCIENTIFIC LITERACY}

Science has been spectacularly successful, with things like international air travel, space flight, and curing of medical illness now routine. The impact of enabling technologies like micro-computers which now dominate much of everyday life, have become available to the general population only as recently as the 1980s. High speed computing and huge increases in cheap, small, memory storage devices is likely to further increase scientific and technological advances.

One feature of the incredible and seemingly ever

Correspondence to: Richard K. Coll, PhD in Science Education, Science and Engineering,University of Waikato, Hamilton, New Zealand

E-mail: r.coll@waikato ac.nz. increasing advance of science and technology is a sense of unease amongst some of the general population about sciences potential to change our lives, in sometimes unpredictable and alarming ways. Public understanding of science and ability to engage in debates about science is part of what is referred to as 'scientific literacy', which according to much recent literature, is of increasing concern worldwide (Carson, 1998; Laugksch, 2000). The term 'scientific literacy' actually represents a diversity of views, but a common theme in the literature is that of being 'learned' or knowledgeable about some science content, and being able to critique scientific debates. According to Laugksch (2000) a scientifically literate person does not accept opinion about a contentious scientific matter uncritically. Rather, he or she wants to see logic or evidence for any stance taken on the issue (Miller, 2000). Some authors argue that the success or otherwise of a 
science education system can be evaluated by reference to the literacy of the citizens (Preece \& Baxter, 2000; Yates \& Chandler, 2000).

It is interesting that many societal scientific debates are characterised by suspicion of scientists themselves, and their purported motives (Durie, 1997). Reiss (2003) suggests "the topics on which scientists work - and so the subject matter of science itself - to some extent reflect the interest, motivations and aspirations both of the scientists that carry out such work and of those who fund them" (p. 154). In other words, technological change is seen to be driven by the motives, interests, and values of the science and technology community, rather than society as a whole (Dalgety, Zegwaard \& McCurdy, 2003; Durie, 1997). This may be one reason that scientists are now seen somewhat as 'tainted witnesses' with a vested interest, or captured by personal interests, unduly influenced by funding providers, such as central government or multinational corporations.

That the science and technology community has such a large impact on technological change would likely be less problematic if the values and culture, and the demographics, of the science community were reasonably representative of society as whole (Reiss, 2003). However, in general this is not the case. Women, for example, are reported to be underrepresented in science and technology higher education faculty posts and other science-related occupations. In a specific example, in the United Kingdom only $12 \%$ of science professors are women (Greenfield, 2000), and a similar lack of representativeness apparently applies to many ethnic minorities. For example, indigenous peoples are reported to be underrepresented in post-compulsory science education and science professions, possibly as a result of perceived conflicts between indigenous worldviews and the worldviews of so-called 'Western science' Jegede \& Okebukola, 1989, 1991; Paku \& Coll, 2005)

It is hard to overestimate the importance of scientific literacy in the modern era. Carson (1998) says we need to "equip students to be good, informed citizens capable of participating in public discourse concerning matters of science" (p. 1007). Important and topical issues relate to matters such as the appropriate use of cloning technologies or genetic modification or engineering (Brunton \& Coll, 2005). Oftentimes the 'right answer' is not obvious for such scientific debates, and the public are faced with trying to decide who is credible in scientific debates. Such debates are hampered by a litany of 'scientific' disasters such as the over-use of pesticides like DDT (Nestle, 2003), and medical mishaps such as thalidomide (Center for Drug Evaluation \& Research, 2002). A dramatic recent example of public debate in which scientists were discredited is that of the UK governments 'scientificallybased' claims that the so-called 'mad cow disease' could not cross the food chain from animals to humans (see Nestle, 2003). This plainly proved incorrect, and helped make the British pubic highly sceptical about scientifically-backed claims for other issues such as GM crops and the like. A strong case for the importance of scientific literacy as a focus for science education is provided by Carson (1998). He comments that "science has become far more than an esoteric body of facts about the natural word" (p. 1011). Scientific literacy also is important in the management of schools and school curricula. With devolution of school management in some countries debates about what should be included in school science curriculum can become quite heated (characterized by creationism vs. evolution debates, see e.g., Dagher \& BouJaoude, 1997; Gould, 1983, 1991a, 1991b; Kass, 1988).

\section{Nature of Science and the 'Scientific Mind'}

An important aspect of scientific literacy is familiarity with the nature of science and scientists. To engage in debate about scientific issues we suggest necessitates some understanding of the nature of science. Much of the success of science has been attributed to the so-called scientific method (Chalmers, 1999), and high standards of evidence for scientific claims and theories. But how does science 'work'? How do scientists obtain data? What data is good data? What are the 'rules of the game' in science? Much has been written about the nature of science, and research into students' understanding of the nature of science. It seems students often see science as a codified body of knowledge that is essentially unable to be challenged (e.g., Pfundt \& Duit, 2000). Much constructivist writings and constructivist-based pedagogies have sought to overcome such notions. Constructivists see scientific knowledge as personally mentally-constructed, based on personal experiences, and influenced to a greater or lesser degree by the social context in which knowledge construction occurs (Good, Wandersee \& St. Julein, 1993; Tobin \& Tippins, 1993).

It seems from the literature that students ascribe scientists fairly stereotypical images and beliefs, as do the general public, seeing them as objective seekers of truth and inevitably ascribing to experimentalist methods of inquiry in their scientific research (Dalgety, Coll \& Jones, 2002). Scientists are, however, humans and like all humans hold views and biases, for example, seeing some things worthy of inquiry and others not (Laugksch, 2000). However, like technology (Sade \& Coll, 2002), science is increasingly presented in the science education literature as contextualized and valueladen, and to possess a 'sociological agenda' (Allchin, 1998). Carson (1998) argues that science education should not "leave students vulnerable to the occasional dogmatism of the scientists, but able to appreciate and 
yet criticise the enterprise of science" (p. 1012). Guisasola, Almudí and Furió (2005) point out that students are likely to see science as codified knowledge (in physics at least) for which textbooks present a very simplified version of the nature of science, one in which science knowledge is seen to be accumulated in "nonproblematic, non-historical, 'linear' accumulation" ( $p$. 333). In contrast, recent work by Dagher and Ford (2005) suggests that science biographies written for children provide insights about scientific experiments and procedures used by scientists, but speak little of how scientists make connections between theory and evidence.

Gauld (2005) in a landmark paper summarizes much research into the 'scientific mind' and scientists' views of the nature of science. This is presented in terms of the 'scientific attitude' (attributed to Gauld \& Hukins, 1980), and 'habits of mind'. According to Guald's (2005) analysis, habits of mind for scientists can include: open-mindedness, scepticism, rationality, objectivity, mistrust of arguments from authority, suspension of belief, and curiosity. A number of these habits of mind at first sight seem incompatible (e.g., open-mindedness and scepticism). However, it is the interplay of these habits of mind that results in 'the scientific attitude', in which "no idea, conclusion, decision or solution is accepted just because a particular person makes a claim but is treated sceptically and critically until its soundness can be judged according to the weight of evidence which is relevant to it" (Gauld, 1982, p. 110). A key feature of evidence claims, according to Zinman (1968), is that scientists have "very high internal critical standards" (p. 79).

Herron (1969) suggests that with respect to the understanding of the nature of science presented in the literature "we 'talk' a much more impressive procedure than we actually do" (p. 105). This resonates nicely with Reif's (1995) view that to understand science involves more than gaining content knowledge; it also involves understanding of the "requisite thought process" of science (p. 281).

The literature is replete with commentary and rhetoric about what scientists are purported to think: their epistemological beliefs (Matthews, 1996), their views about the nature of science (Matthews, 1998), conflicts between science and religion (e.g., Gauld, 2005; Mahner \& Bunge, 1996a, 1996b), and superstitious/pseudoscientific beliefs (Preece \& Baxter, 2000; Yates \& Chandler, 2000). But according to Coll and Taylor (2004) there are little data reported from contextualized and detailed research studies about scientists' views of the nature of science, and conflicts between scientific and everyday thinking.
Theoretical Basis to the Inquiry: Science as Sociocultural Practice

The construction of science as a culture, where belonging is characterised by the enculturation or assimilation of cultural norms, is consistent with sociocultural learning theories (Lave \& Wenger, 1991). Sociocultural learning theories see cognition as 'constructed jointly', and learning being strongly influenced by social, cultural and historical factors. According to (Wertsch, 1991, p. 86) "the basic tenet of a sociocultural approach to mind is that human mental functioning is inherently situated in social, interactional, cultural, institutional, and historical context". Thus, the science community of practice cannot be divorced from the social, cultural and historical elements of their own identity and the workplace itself. To understand these norms and practices of the scientific community requires some form of enculturation into the community of practice; something that is not open to the public. Enculturation into a community of practice involves the learning of skills, knowledge and understandings (e.g., in science, the scientific method, accuracy, repetition, etc.) all within a particular sociological framework (Evans \& Heidegger, 1999). The general public may not see any great need to become 'enculturated into science'. However, it is our contention here that a facet of scientific literacy involves just this. In other words, here we argue that to become scientifically literate, people need to have at least some understanding of what science is and how scientists go about their business (for a counter to this position see Ben-Ari, 2005). Specifically, here we are concerned with what scientists consider to be 'scientific evidence' for a proposition or propositions. Understanding how scientist work, we suggest would enable students and the public to engage in more informed scientific debates.

\section{Research Aim and Questions}

Our overview of the literature here suggests that scientific literacy is an important and current educational issue. It also suggests that, with a few exceptions, scientists are seen by the public and in science education writings in stereotypical images. Research and writings about scientists' views of the nature of science tend to focus on 'hard science' concepts with, for example, Franklin (2002) exploring this notion in physics by examination of rationalisation about relativistic quantum mechanics, concepts beyond the vast bulk of the general public (or indeed most physicists!). Here we sought to explore the issue of scientific literacy and scientist habits 
of mind, by drawing on current issues that the general public encounter and is familiar with: namely, pseudoscientific beliefs and superstitions, and religious beliefs.

Gauld (2005) points out that scientists may hold two positions: a rationalist stance which is that presented in the public domain (the public domain of their community of practice), and the private idiosyncratic views more accessible by interpretivist, ethnographic educational research approaches. The issue of scientific literacy in this work is thus explored by a qualitative, indepth, investigation of scientists' views of scientific evidence. The overarching aim is: How do scientists judge evidence claims? The research reported here comprises two intensive interpretivist-based studies. The first study is concerned with scientists' superstitious beliefs (some details of which have been presented elsewhere, Coll \& Taylor, 2004). The second concerned potential conflicts between scientific theories and evidence, and scientists' religious beliefs.

\section{METHODOLOGY AND METHODS}

The methodology derived from the socioculturalbased theoretical framework described above comprised two methods: surveys and interviews. The details of these are now described in turn.

\section{The Surveys}

We made use of two instruments in which participants are asked to respond to a four-point scale ranging from 'I believe that this is almost certainly true' to 'I believe that this is almost certainly untrue' with two in-between responses qualified by replacing 'almost certainly' with 'quite likely'.

\section{Table 1. Items from Exeter instrument (Preece \& Baxter, 2000)}

The positions of the stars and planets when you are born affect what will happen to you during your life Some houses are haunted by ghosts

It is possible to tell what is going to happen to you in the future by studying the lines on the palms of your hands

Wearing jewelry made out of certain crystals can help to keep you healthy

Some men and women can find missing persons by swinging a pendulum over a map

In the past aliens from some other planet have landed on Earth

Breaking a mirror is likely to bring you some bad luck in the future

The 13th of July 2001 is a Friday and people should be careful on that day as 'Friday the 13th is unlucky'
The first instrument was based on previous work by Preece and Baxter (2000), the Exeter superstitions instrument, in which respondents are presented with a series of item statements, which these authors considered to be superstitions (e.g., Some houses are haunted by ghosts; Some men and women can find missing persons by swinging a pendulum over a map; and In the past aliens from some other planet have landed on Earth) (Table 1).

The second instrument, developed by the authors, contains 18 assertions or propositions that were deemed by a panel of experts to consist of potential conflicts between religious beliefs and scientific theories (Table 2). Sample items included: People can be cured of serious ill health by petition to a higher spiritual power; The age of the earth is no more than 10,000 years old; After death the soul/spirit of a person returns in a subsequent life form; and, Human conception can occur by spiritual not physical means.

\section{Table 2. Items from religion and science instrument (Preece \& Baxter, 2000)}

The age of the earth is no more than 10,000 years old After death the soul/spirit of a person continues to exist

After death the soul/spirit of a person returns in a subsequent life form

What happens in a person's life is set at the beginning of their life

A person can affect what happens in their life by petition to a higher spiritual power

Human conception can occur by spiritual and not physical means

People can be cured of serious ill health by petition to a higher spiritual power

Order in the universe exists as a result of the influence of a higher spiritual power

Evil behavior in the world occurs as a result of powerful evil spiritual forces

Inspiration for arts, sciences and crafts is a

consequence of spiritual forces

The lives and activities of all living things are influenced by spiritual forces

There are benevolent spiritual forces that assist or protect people in their daily lives

Some particular animals have special spiritual status

All living and inanimate things have a soul/spirit

associated with them

Disasters that occur in the world are a result of

powerful evil spiritual forces

Disasters that occur in the world are a result of people's evil behavior

People who behave well are rewarded in an afterlife Humans are distinguished from other animals as a result of having a soul/spirit 


\section{Instrument Validation}

Validation of terms like superstition, and of what constituted current science views and conflicts with those views, was achieved by the use of a panel of experts. The panel of experts consisted of scientists across a range of disciplines that examined each item statement in the instruments and asserted that it was in conflict with current scientific thinking in that discipline. These individuals had no contractual interest in the study (Guba \& Lincoln, 1989), and were not participants in the inquiry (other than in this advisory capacity). Propositions about religious beliefs were chosen to access beliefs purported to come from several religious faiths and denominations: Catholic, Fundamentalist Christian (viz., Christians who believe in the literal interpretation of the Bible); Sunni Islam, Judaism, Buddhism, Hinduism, and Bahá'i (based on religious writings and unstructured interviews with religious ministers and faith adherents for each of the above named religions).

\section{Survey Administration}

The term superstition did not appear on our version of Exeter instrument used in the present work, nor was it used in the interviews (except when introduced by participants). In the first study, as a first step, the researchers administered the Exeter instrument to a number of scientists working in industry and in tertiary education $(n=40)$. The purpose of this was not to replicate earlier quantitative work as such, but was to ascertain if scientists agreed with any of the beliefs presented on the Exeter instrument (i.e., provided any response other than 'I believe that this is almost certainly untrue'). The reason for this was that the reported development of the Exeter instrument appears to assume that all scientists would automatically disbelieve all the propositions presented to them (Preece \& Baxter, 2000). Clearly there would be little point in the present research if this was in fact the case. A similar thing was done with the religious beliefs instrument. Our initial survey of scientists suggested that a cohort of scientist did not dismiss all propositions

Table 3. Demographics of research participants: Superstitions study

\begin{tabular}{|c|c|c|c|}
\hline Pseudonym & Discipline & Academic Status/Experience & Comments \\
\hline Brian & Chemistry & $\begin{array}{l}\text { Associate Professor/experienced researcher } \\
\text { experienced in administration \& management }\end{array}$ & \\
\hline Miles & Chemistry & $\begin{array}{l}\text { Senior Lecturer/established researcher with } \\
\text { emerging international reputation }\end{array}$ & \\
\hline Charlie & Biology & $\begin{array}{l}\text { Lecturer/new appointee with modest research } \\
\text { reputation, although emerging in his field }\end{array}$ & \\
\hline Richard & Earth sciences & $\begin{array}{l}\text { Associate Professor/experienced researcher; } \\
\text { experienced in administration \& management }\end{array}$ & \\
\hline Peter & Physics & Lecturer/emerging researcher & \\
\hline Terry & Chemistry & $\begin{array}{l}\text { Senior Lecturer/emerging researcher with, but } \\
\text { considerable administrative experience }\end{array}$ & \\
\hline Nikki & Chemistry & Lecturer/emerging researcher & \\
\hline Mack & Physics & Senior Lecturer/emerging researcher & \\
\hline Anne & Biology & Lecturer/emerging researcher & Strongly identified as atheist \\
\hline Mary & Physics/Biology & Senior lecturer & \\
\hline Sue & Biology & $\begin{array}{l}\text { Teacher/emerging researcher with limited reputation } \\
\& \text { administrative experience }\end{array}$ & \\
\hline Jane & Biology & $\begin{array}{l}\text { Lecturer/emerging researcher with some } \\
\text { administrative experience }\end{array}$ & \\
\hline Teresa & Environmental science & $\begin{array}{l}\text { Senior Lecturer/experienced researcher with } \\
\text { experience in administration \& management }\end{array}$ & \\
\hline Fiona & Chemistry & $\begin{array}{l}\text { Lecturer/emerging researcher with considerable } \\
\text { administrative experience }\end{array}$ & \\
\hline Judy & Mathematics/Psychology & $\begin{array}{l}\text { Lecturer/emerging researcher with considerable } \\
\text { administrative experience }\end{array}$ & \\
\hline Josie & Human biology & $\begin{array}{l}\text { Lecturer/experienced researcher with experience in } \\
\text { administration \& management }\end{array}$ & \\
\hline Theo & Biochemistry & $\begin{array}{l}\text { Senior lecturer/experienced researcher with } \\
\text { experience in administration \& management }\end{array}$ & \\
\hline Nigel & Mathematics & $\begin{array}{l}\text { Lecturer/emerging researcher with some } \\
\text { administrative experience }\end{array}$ & $\begin{array}{l}\text { Strongly identified as 'born- } \\
\text { again' Christian }\end{array}$ \\
\hline
\end{tabular}


Table 4. Demographics of research participants: Religion and Science study

\begin{tabular}{|c|c|c|c|}
\hline Pseudonym & Religion & Occupation/Discipline & Qualification \\
\hline Gerrad & $\begin{array}{l}\text { Church of } \\
\text { England }\end{array}$ & Lecturer in biology & $\mathrm{PhD}$ \\
\hline William & Presbyterian & Lecturer in biology & $\mathrm{PhD}$ \\
\hline Bob & Hindu & Lecturer in physics & $\mathrm{PhD}$ \\
\hline Mary & Catholic & Lecturer in biology & $\mathrm{PhD}$ \\
\hline Arnie & Methodist & Lecturer in agroscience & $\mathrm{PhD}$ \\
\hline Susan & Agnostic & Lecturer in agroscience & $\mathrm{PhD}$ \\
\hline Phil & Agnostic & Lecturer in agroscience & $\mathrm{PhD}$ \\
\hline Iman & Sunni Muslim & Completing $\mathrm{PhD}$ in agroscience & MSc \\
\hline Ahmad & Sunni Muslim & Completing $\mathrm{PhD}$ in materials \& process engineering & MSc \\
\hline Mahmoud & Sunni Muslim & Food and meat researcher & $\mathrm{PhD}$ \\
\hline Jack & Catholic & Lecturer in biology & $\mathrm{PhD}$ \\
\hline Allan & Bahá’í & Resource consent manager & MSc Environmental Science \\
\hline Celia & Hindu & Earth Science & MPhil \\
\hline Anne & Hindu & Completing $\mathrm{PhD}$ in materials \& process engineering & MSc \\
\hline Brian & Bahá’í & Pharmacist & BPharm \\
\hline Lyle & Bahá’í & Marine biologist & $\mathrm{PhD}$ \\
\hline Liam & Christian & Completing PhD in chemistry & MSc \\
\hline Kevin & Christian & Completing $\mathrm{PhD}$ in the Earth sciences & MSc \\
\hline Patty & Buddhist & Chemist & MSc \\
\hline John & Buddhist & Chemist & MSc \\
\hline Rachel & Buddhist & Physicist & MSc \\
\hline James & Buddhist & Physicist & MSc \\
\hline
\end{tabular}

in the instruments. Hence, we subsequently interviewed two cohorts of science faculty in two separate studies. For the superstitions work, there were 18 participants interviewed, with none of the original 40 scientists surveyed. For the religion and science study, we administered the instrument to a cohort of $20 \mathrm{New}$ Zealand and Australian scientists in advance of interviews (see below).

\section{Interviews}

The second phase of the work involved intensive one-on-one semi-structured interviews based on the responses made to the administered instruments. This involved an approach in which individual constructions were elicited by interactive dialogue between the researchers and the participants (Good, Wandersee \& St. Julien, 1994). This dialogue was conducted on 'neutral ground' in order to reduce the influence of investigator bias (Johnson \& Gott, 1996). In practical terms this consisted of the interviewers constantly working to ensure undistorted communication took place: words and beliefs that hold an 'established' meaning (e.g., a 'superstition', a specific religious belief or an 'established' scientific theory) were only ascribed the meaning imparted to them within the conversation of the interviews (see also below, terms like 'higher power', 'spirit' and 'soul').
In the interview protocol, the participants were first asked to complete the instrument (in advance of interviews) and the responses formed the basis for a series of probing, in-depth interviews, that addressed their responses and other topics not presented in the instrument that arose during discourse (such as water divining, acupuncture, etc.). It is important to note at this point that the researchers did not seek to exclude beliefs introduced by the participant (religious beliefs, medical-related beliefs, etc.), whether they were on either of the instruments or not. In these interviews the researchers' focus was not on a particular belief, or belief type (as identified in the literature, or held by the researchers); rather we strived to ascertain the basis on which the scientists had arrived at their beliefs about the propositions contained in the instruments, and any other beliefs respondents introduced in the conduct of the interviews.

\section{Sample}

The samples were convenience samples, but interview participants were chosen purposively to provide a reasonably even gender balance, and a range of scientific disciplines (chemistry, the Earth and biological sciences, physics, etc.). For the superstitions work there were two cohorts from two 'conventional' tertiary or higher education institutions (i.e., institutions 
which were founded as universities rather than originating as polytechnics and/or universities of technology): one from New Zealand the other from the UK. For the religion and science study all participants were from conventional tertiary institutions based in New Zealand and Australia (Tables 3 \& 4).

The participants were typically highly educated with about half holding a master's degree and half a doctoral degree. Half of the master's graduates are currently studying towards doctorate. Those employed, were working as faculty or research scientists in their disciplines. This group ranged from relatively new staff appointments with two or three years experience, to experienced people with senior-level research and management responsibilities. About half of the participants had an international reputation for research in their disciplines, possessing substantial research publications in international journals and other peer recognition such as long term service on editorial boards for journals. Participants were recruited by means of a letter of invitation that confirmed the use of pseudonyms and assured them of confidentiality.

For the religion and science study, we sought participants with a variety of faith commitments. First were those who were raised in a faith, practiced that faith as children and young persons, and who now described themselves as 'non-practicing'. The intention here was to see if these individuals had 'drifted away' from their beliefs and religious convictions for no particular reason, or if this occurred because they encountered conflict between religious beliefs as they became enculturated into their particular scientific community. Second, we sought participants who were strong faith-adherents and currently strongly practicing in their faith (as identified by the participants - i.e., they reported that they were currently practicing their faith in terms of religious observance and rituals). The intention here was to see if, for example, a strong Christian was more inclined to 'accept' Christian beliefs that were in conflict with scientific theories than they were about say Hinduism or Bahá'í beliefs that were in similar conflict, and vice versa.

\section{Researchers' Viewpoints and Background}

The researchers in this work come from different educational and religious backgrounds. Given the nature of the present work (i.e., dealing with an emotive and complex topic), it is appropriate for the authors to describe their background in order for the reader to aware of any potential biases and to aid in interpretation of our research findings.

One researcher was brought up in a relatively strict Catholic background. He was and still is a 'practicing Catholic' in that he attends Sunday observances and other Catholic obligations regularly. $\mathrm{He}$ is a scientist with a doctorate in chemistry and record of publishing on organomentallic chemistry. He also is a science education researcher with a second doctorate, and publishing record in science education. Metaphysically he ascribes to constructivist views and acknowledges social influences on scientific and educational research. A second researcher is from a church-going Protestant Christian background. He is still a tentative believer but no longer attends church on a regular basis. He has a doctorate in science education and came from a science background, having completed undergraduate and postgraduate degrees in the biological sciences. Like the above researcher, he ascribes to constructivist views and acknowledges the social component of research. A third researcher was raised as an atheist and was converted to the Bahá'í Faith at high school as a result of extensive intellectual discussions with a strong Bahá'i adherent. $\mathrm{He}$ is an engineer with a doctorate in materials and process engineering and has an undergraduate degree in the biological sciences. He is a social-constructivist in epistemology, but subscribes to a scientific objectivist methodology for his scientific/engineering research. $\mathrm{He}$ is broad in agreement with an interpretive-based research approaches to science education research in that he recognizes the importance of subjective views in both learning and research in education.

\section{Data Analysis}

Data analysis for the instruments employed simple summaries of frequency distribution. In the case of the interviews, these were audiotaped and transcribed verbatim. Interview transcripts were examined for statements about the scientists' views in an iterative process based on a phenomenographic approach allowing pools of meaning, and subsequent categories of description, to arise from the data (Marton \& Booth, 1997) (Tables 5,6 \& 7). Portions of transcripts are used to illustrate the process of analysis and interpretation, and pseudonyms are used throughout this report of the research. These have undergone light and minor editing (e.g., removal of repeated words, changes of tense) in a few cases, purely to make them more readable consistent with an interpretive approach to educational research. In accord with an interpretive, socioculturalbased approach, the research findings reported here are not directly generalizable to other settings. An alternative, and that applicable here, is the notion of transferability (Guba \& Lincoln, 1989) in which the reader evaluates the significance of the findings in his or her own educational context. The provision of descriptive findings (see below), using the so-called 'thick description' is intended to facilitate this process (Merrian, 1988; Peshkin, 1993). 
Table 5. Rationale for scientists' beliefs for Exeter instrument

\begin{tabular}{|c|c|c|c|c|}
\hline \multirow{2}{*}{$\begin{array}{l}\text { Belief } \\
\text { Astrology }\end{array}$} & \multirow{2}{*}{$\begin{array}{l}{ }^{1} \text { Agreement } \\
\text { Sceptical }\end{array}$} & \multirow{2}{*}{$\begin{array}{l}\text { Reason(s) For } \\
\text { Theoretical basis }\end{array}$} & \multicolumn{2}{|c|}{ Reason(s) AgainstExample(s) For/Example(s) Against } \\
\hline & & & $\begin{array}{l}\text { Testimony; } \\
\text { Theoretical basis; } \\
\text { Experiments }\end{array}$ & $\begin{array}{l}\text { Physical nature of planetary position/Used to make } \\
\text { money; no physical link; no evidence for link; } \\
\text { minimal effects because of distance; No correlations }\end{array}$ \\
\hline $\begin{array}{l}\text { Ghosts } \\
\text { Palmistry }\end{array}$ & $\begin{array}{l}\text { Not s } \\
\text { Scept }\end{array}$ & experience & Testimony & Related to Ouija board experiences \\
\hline Crystals & Not sceptical & $\begin{array}{l}\text { lony \& } \\
\text { etical basis }\end{array}$ & $\begin{array}{l}\text { Testimony; } \\
\text { Theoretical basis; } \\
\text { Alternative } \\
\text { explanations }\end{array}$ & $\begin{array}{l}\text { Crystals exert electrical \& field effects/Friends } \\
\text { beliefs seen as uncritical; No chemical reasons for } \\
\text { effects by quartz; Happened because of some other } \\
\text { factor }\end{array}$ \\
\hline $\begin{array}{l}\text { Missing persor } \\
\& \text { pendulum }\end{array}$ & s'Tota & None & Theoretical basis & None/No connection between map and pendulum \\
\hline Aliens & Open & Don't know enough & Testimony & $\begin{array}{l}\text { Possible aliens landed in past; Nature of alien life; } \\
\text { Roswell incident; paradigm shifts/Unreliable } \\
\text { witness 'elderly' or 'children' }\end{array}$ \\
\hline Mirror & Tot & Non & al Dasis & /Seen as socially \\
\hline Friday 13 & Totally sceptical & None & Theoretical basis & None/Seen as socially grounded \\
\hline
\end{tabular}

Table 6. Rationale for scientists' beliefs for superstitions interviews

\begin{tabular}{|c|c|c|c|c|}
\hline Belief & ${ }^{1}$ Agreement & Reason(s) For & Reason(s) Against & Example(s) For/Example(s) Against \\
\hline Water divining & Not sceptical & Theoretical basis & None & Physical interaction between objects/None \\
\hline Ouija board & Open & Personal experience & Theoretical basis & $\begin{array}{l}\text { Dramatic personal event - lights fusing/No } \\
\text { possible credible explanation }\end{array}$ \\
\hline Acupuncture & Not sceptical & Testimony & None & Doctors seen as credible/None \\
\hline $\begin{array}{l}\text { Identification } \\
\text { of gender }\end{array}$ & Not sceptical & Personal experience & None & Own pregnancy/None \\
\hline $\begin{array}{l}\text { Destiny/Predet } \\
\text { ermination }\end{array}$ & Sceptical & $\begin{array}{l}\text { Theoretical basis; } \\
\text { Personal beliefs }\end{array}$ & Personal beliefs & $\begin{array}{l}\text { Quantum effects, probability; } \\
\text { genetics/Peoples' choices effect own destiny }\end{array}$ \\
\hline Birth rates & Sceptical & None & Testimony & None/Birth rates in study \\
\hline Numeracy & Sceptical & None & Theoretical basis & None/Seen as socially grounded \\
\hline Clairvoyance & Sceptical & Experiments & Experiments & Nostradamus/Police inquiry failure \\
\hline $\begin{array}{l}\text { Psychic/Parano } \\
\text { rmal }\end{array}$ & Sceptical & None & Experiments & None/Police inquiry failure \\
\hline $\begin{array}{l}\text { Interplanetary } \\
\text { life }\end{array}$ & Open & Don't know enough & None & $\begin{array}{l}\text { Statistical probability of life elsewhere; Lack } \\
\text { of knowledge of brain and its } \\
\text { functions/None }\end{array}$ \\
\hline UFOs & Open & $\begin{array}{l}\text { Testimony/Don't know } \\
\text { enough }\end{array}$ & None & Pilots seen as credible/None \\
\hline $\begin{array}{l}\text { Archaeological } \\
\text { events }\end{array}$ & Open & Don't' know enough & None & Nasca Lines in Peru; Stonehenge/None \\
\hline
\end{tabular}

\section{RESEARCH FINDINGS}

The research findings are summarized in Table 8, and here we provide a brief overview of the findings before presenting them in more detail. Some of these themes were reasons given by the scientist for supporting the instrument propositions, others were reasons for disbelieving them - these differences are detailed under individual headings. The themes discerned included: Personal experience/Personal beliefs; Testimony from other scientists; Potential theoretical basis/Related evidence; and that We don't know enough.

\section{Personal Experiences}

The scientists recognised the influence of personal experience in the formation of their own beliefs. Some personal experiences were seen to influence the scientists thinking about beliefs, making them at least potentially believable. Josie, for example, felt there was some prospect that one could tell the sex of a baby based on her own personal experiences during childbirth: "I had twins and I was attached to blood pressure monitors, two monitors, one for each twin, picking up blood pressures and their heart rates towards the end of the pregnancy and there were differences." 
Table 7. Rationale for scientists' beliefs for religion and science interviews

\begin{tabular}{|c|c|c|c|c|}
\hline$\overline{\text { Belief }}$ & ${ }^{1}$ Agreement & Reason(s) For & $\begin{array}{l}\text { Reason(s) } \\
\text { Against }\end{array}$ & $\begin{array}{l}\text { Example(s) For/Example(s) } \\
\text { Against }\end{array}$ \\
\hline $\begin{array}{l}\text { Age of the Earth Less 10,000 } \\
\text { Years }\end{array}$ & Sceptical & Theoretical Basis & Testimony & $\begin{array}{l}\text { Changes to speed of light influences } \\
\text { dating experiments \& metaphorical } \\
\text { age/Scientific evidence of fossils, } \\
\text { dating experiments, etc. }\end{array}$ \\
\hline Soul/Sprit Exists after Death & Not Sceptical & $\begin{array}{l}\text { Testimony/Don't } \\
\text { Know Enough }\end{array}$ & $\begin{array}{l}\text { Theoretical } \\
\text { Basis }\end{array}$ & $\begin{array}{l}\text { Near death } \\
\text { experiences/Indoctrination }\end{array}$ \\
\hline $\begin{array}{l}\text { Soul/Spirit Returns in } \\
\text { Subsequent Life Form }\end{array}$ & Not Sceptical & $\begin{array}{l}\text { Testimony/Don't } \\
\text { Know Enough }\end{array}$ & $\begin{array}{l}\text { Theoretical } \\
\text { Basis }\end{array}$ & $\begin{array}{l}\text { Affinity with things Russian \& } \\
\text { Revolution/ }\end{array}$ \\
\hline $\begin{array}{l}\text { What Happens in Life Set at } \\
\text { Beginning of Life }\end{array}$ & Sceptical & $\begin{array}{l}\text { Personal } \\
\text { Experience/ } \\
\text { Don't Know } \\
\text { Enough }\end{array}$ & $\begin{array}{l}\text { Theoretical } \\
\text { Basis }\end{array}$ & $\begin{array}{l}\text { Marriage \& wealth prediction came } \\
\text { true and / }\end{array}$ \\
\hline $\begin{array}{l}\text { Petition of Higher Spiritual } \\
\text { Power }\end{array}$ & Open & $\begin{array}{l}\text { Personal } \\
\text { Experience/Testim } \\
\text { ony }\end{array}$ & $\begin{array}{l}\text { Theoretical } \\
\text { Basis }\end{array}$ & $\begin{array}{l}\text { Successful personal petition/Failed } \\
\text { personal petition } \& \text { mere act of } \\
\text { petition }\end{array}$ \\
\hline $\begin{array}{l}\text { Human Conception Can Occur } \\
\text { by Spiritual Means }\end{array}$ & Sceptical & Theoretical Basis & $\begin{array}{l}\text { Theoretical } \\
\text { Basis }\end{array}$ & $\begin{array}{l}\text { Sexual reproduction necessary \& } \\
\text { social factors e.g. of purity/Amictic } \\
\text { cells }\end{array}$ \\
\hline $\begin{array}{l}\text { Ill Health Cured by Petition to } \\
\text { Higher Spiritual Power }\end{array}$ & Open & Testimony & $\begin{array}{l}\text { Theoretical } \\
\text { Basis }\end{array}$ & $\begin{array}{l}\text { Successful personal petition/Failed } \\
\text { personal petition \& mere act of } \\
\text { petition }\end{array}$ \\
\hline $\begin{array}{l}\text { Order in Universe Exists } \\
\text { Because of Higher Spiritual } \\
\text { Power }\end{array}$ & Sceptical & $\begin{array}{l}\text { Don't Know } \\
\text { Enough }\end{array}$ & $\begin{array}{l}\text { Theoretical } \\
\text { Basis }\end{array}$ & Order \& structure of animals/ \\
\hline $\begin{array}{l}\text { Evil Behavior Exists Because of } \\
\text { Evil Spiritual Forces }\end{array}$ & Sceptical & $\begin{array}{l}\text { Personal } \\
\text { Experience }\end{array}$ & $\begin{array}{l}\text { Theoretical } \\
\text { Basis }\end{array}$ & Grandfathers death/Schizophrenia \\
\hline $\begin{array}{l}\text { Inspiration for Arts, Science, } \\
\text { Craft Consequence of Spiritual } \\
\text { Forces }\end{array}$ & $\begin{array}{l}\text { Totally } \\
\text { Sceptical }\end{array}$ & None & $\begin{array}{l}\text { Theoretical } \\
\text { Basis }\end{array}$ & None/No potential link \\
\hline $\begin{array}{l}\text { Lives/Activities of Living Things } \\
\text { Influenced by Spiritual Forces }\end{array}$ & $\begin{array}{l}\text { Totally } \\
\text { Sceptical }\end{array}$ & None & $\begin{array}{l}\text { Theoretical } \\
\text { Basis }\end{array}$ & None/No potential link \\
\hline Benevolent Spiritual Forces & Not Sceptical & Personal & Theoretical & \\
\hline Assist/Protect People & & $\begin{array}{l}\text { Experience/Testim } \\
\text { ony }\end{array}$ & Basis & \\
\hline $\begin{array}{l}\text { Particular Animals Have Special } \\
\text { Spiritual Status }\end{array}$ & Sceptical & $\begin{array}{l}\text { Personal } \\
\text { Experience }\end{array}$ & $\begin{array}{l}\text { Theoretical } \\
\text { Basis }\end{array}$ & $\begin{array}{l}\text { Encounter with native birds/Lack of } \\
\text { logic-punishment coming back as } \\
\text { animal }\end{array}$ \\
\hline $\begin{array}{l}\text { Living \& Inanimate Things Have } \\
\text { Soul/Spirit }\end{array}$ & Sceptical & None & $\begin{array}{l}\text { Theoretical } \\
\text { Basis }\end{array}$ & \\
\hline $\begin{array}{l}\text { Disasters Due to Evil Spiritual } \\
\text { Forces }\end{array}$ & Sceptical & None & $\begin{array}{l}\text { Theoretical } \\
\text { Basis }\end{array}$ & $\begin{array}{l}\text { Auto suggestion - 'pointing the } \\
\text { bone'/ }\end{array}$ \\
\hline $\begin{array}{l}\text { Disasters Due to Peoples Evil } \\
\text { Behavior }\end{array}$ & Sceptical & None & $\begin{array}{l}\text { Theoretical } \\
\text { Basis }\end{array}$ & $\begin{array}{l}\text { None/Disasters due to bad } \\
\text { behaviour \& natural disaster no- } \\
\text { ones fault }\end{array}$ \\
\hline $\begin{array}{l}\text { People Who Behave well } \\
\text { Rewarded in Afterlife } \\
\text { Humans But Not Animals Have } \\
\text { Soul/Spirit }\end{array}$ & $\begin{array}{l}\text { Not Sceptical } \\
\text { Sceptical }\end{array}$ & $\begin{array}{l}\text { Personal Beliefs } \\
\text { None }\end{array}$ & $\begin{array}{l}\text { Theoretical } \\
\text { Basis } \\
\text { Theoretical } \\
\text { Basis }\end{array}$ & \\
\hline
\end{tabular}

\footnotetext{
${ }^{1}$ Key:

Exeter Responses (all participants): Totally Sceptical, only response was 'T believe this was almost certainly untrue'; Sceptical, most common response was I believe this was almost certainly untrue'; Not sceptical, at least some respondents indicated 'I believe this was almost certainly true' or 'I believe this is quite likely to be true; Open, most respondents indicated 'I believe this was almost certainly true' or 'I believe this is quite likely to be true'.

Interview Responses (participants who identified this belief spontaneously during interviews for both superstitions and religion \& science studies): Totally Sceptical, respondent was dismissive of all propositions/beliefs discussed during interviews; Sceptical, respondent that raised this issue was dismissive of this belief; Not sceptical, respondent that raised this issue was fairly dismissive of this belief, but did not totally discount the belief; Open, respondent that raised this issue indicated that they agreed with this belief.
} 
Table 8. Classification of scientists' views for evidence claims for superstitions and religion and science studies

\begin{tabular}{|c|c|c|}
\hline Classification & Basis & Comment \\
\hline Personal experience/ & The scientist had undergone personal experience of the type & Some dramatic personal experiences were \\
\hline Personal Beliefs & \multicolumn{2}{|c|}{$\begin{array}{l}\text { discussed/The scientists held strong personal beliefs about thestrongly influential } \\
\text { topic }\end{array}$} \\
\hline Testimony & $\begin{array}{l}\text { The scientists rated personal testimony of others, typically } \\
\text { media-based, either as credible or non-credible; Credible } \\
\text { witnesses were educated people or experts (e.g., medical } \\
\text { people or airline pilots) non-credible witnesses were either } \\
\text { 'gullible', 'charlatans', 'children or the 'elderly' }\end{array}$ & $\begin{array}{l}\text { Most widely held basis for believing or } \\
\text { dismissing belief }\end{array}$ \\
\hline Theoretical basis & $\begin{array}{l}\text { The scientists perceived a possible theoretical basis to the } \\
\text { belief }\end{array}$ & $\begin{array}{l}\text { Commonly related to scientists' own } \\
\text { discipline or area of expertise }\end{array}$ \\
\hline $\begin{array}{l}\text { Experimental } \\
\text { evidence }\end{array}$ & $\begin{array}{l}\text { Controlled, quantitative experiments, actual or hypothetical, } \\
\text { seen to be able to provide evidence for/against the belief }\end{array}$ & $\begin{array}{l}\text { The scientists were highly sceptical about } \\
\text { 'apparent' evidence claims of this nature, } \\
\text { but were willing to consider such } \\
\text { propositions }\end{array}$ \\
\hline Simple alternative & $\begin{array}{l}\text { The scientists were convinced that even with strong empirical } \\
\text { evidence supporting the belief, there would be a simple, } \\
\text { underlying alternative explanation }\end{array}$ & $\begin{array}{l}\text { The scientists were highly sceptical about } \\
\text { 'apparent' evidence claims of this nature }\end{array}$ \\
\hline Don’t know enough & $\begin{array}{l}\text { The scientists felt current knowledge about the belief was } \\
\text { inadequate to either support or dismiss the belief }\end{array}$ & $\begin{array}{l}\text { Commonly related to probability } \\
\text { arguments, e.g., with respect to space/aliens }\end{array}$ \\
\hline
\end{tabular}

Some reported personal experiences were highly dramatic and unsettling, clearly exerting a significant impact on the scientists. The most compelling example was that provided by Theo when he talked of his experiences with an Ouija board (a movable 'board' that is thought by some to provide a means of communicating with dead people or 'spirits'). His response to the proposition that some houses are haunted by ghosts was that he thought this was almost certainly true. He explains his reasoning, based on a personal experience: "Threats were made against a particular woman in the group and the timing of that and in the lead up to that potential action we were corresponding with whatever was going on saying that we forbade it etc, etc. But whatever was happening was getting more and more excited and the climax of the exercise was the lights fusing in the house."

Personal experience likewise emerged as a reason for believing some religious propositions with, for example, some scientists reporting friends and colleagues being cured of significant illness (e.g., cancer) by 'petition to a higher power'. This was in some cases seen as resulting from what Bob called "the mere act of petition," and in other cases from the actual intervention of a higher power as seen in Phil's comment that 'I know that in the intervention of God, there is clear evidence in healing." Those who opposed such interventions generally felt that the notion of 'mind over matter' was the overriding influence as seen in Steve's comment that " 'pointing the bone' [an Australian aboriginal indigenous custom of placing a curse on a person, by literally pointing a bone at them], that sort of thing in [Australian] Aboriginal or African culture, if you believe you've done something wrong, it could be because a higher power intervened, or it could be because of a belief that was self-fulfilling." Personal experiences reported included Bob's experience of physical encounter with a native bird species [the native bird showed affinity for his presence] which he considered as potential support for a proposition that "some animals have a special spiritual status" and Jim's personal links and affinity with things Russian which he appeared to consider as potential evidence for having lived a past life. 'One of the other things is that my birthday is on the day of the Russian Revolution.'

As was seen in our study of scientist views about superstitions some personal religious experiences reported in the present work were dramatic, and strongly influential on participants' beliefs. This is illustrated in the case of a strongly-practising Hindu participant, who talked of a dramatic personal experience involving 'spirits'. Celia said: "When my grandfather died I was a little girl at the time my mother was looking after him at the hospital and he said wanted to see me...my mum took holidays for me from the school and I went with my mother to visit him in hospital and he died at the hospital - but the second it really happened that his spirit got into me and maybe three or four months later everyday at 12 O'clock afternoon midday I used to get fits."

Similar reasoning was used by Celia to explain the common Hindu support for pre-destination (as probed in an item, 'what happens in a persons life is set at the beginning of their life') which she interpreted as being astrologically-related: "Even now everyone [i.e., in India] decides when you get married, or where you go. We were seven students and he [a pundit-astrologer] said you should be married at 29 and you'll be very rich 
and be owning a car at that time. I never believed it at that time, but definitely next time. I brought a car here [i.e., in NZ]."

The converse also was true in that lack of, or nonfulfilling personal experiences were deemed to be evidence against some propositions. To illustrate, Celia apparently did not accept that 'a person can be affected in their personal life by petition to a higher spiritual power' (item 5, appendix) as the result of failed petition: "I was once thinking that if I pray to God I would get good marks, it never happens, I have to study to get good marks. So I slowly understand that it doesn't happen."

\section{Personal Beliefs}

Likewise personal beliefs based in religion, with no supporting 'evidence', or indeed any perceived need for evidence, was used as a basis for acceptance of some of the propositions in the item statements used in the interviews. Alan was rather dismissive of Hindu-based beliefs in reincarnation and the special status of some animals: "I guess the evidence for reincarnation is flawed in that there's not much point to the exercise... why come back as a cow as a punishment?"

As might be expected, although most participants were more accepting of their own religious beliefs, when they conflicted with science this was not universally accepted. For example, Annie was brought up and remained a practicing Hindu. However, when probed about reincarnation she commented: "In Hinduism there is a thing called reincarnation... when people ask if I believe in reincarnation, not I don't, but I believe the soul lives on," a statement more in accord with Christian religious belief, than Hindu.

\section{Witnesses Testimony}

The bulk of the 'evidence' in favour of, or against, pseudoscientific and superstitious beliefs was judged to come from witnesses and their testimony. Such witnesses were typically seen as lacking in credibility. These non-credible witnesses fell into two categories; honest individuals who were genuinely misguided, and those with more dubious motives - the latter typically people associated with the entertainment industry, or the mass media.

Some of the non-credible witnesses were seen to be influenced by social mores such as the popularity of reporting alien sightings. Much of this was thought to arrive from television and other mass-media sources such as popular magazines: 'I think it's used as an industry to make money. It's a populist thing." Some of the scientists were highly cynical, distrusting motives and credibility of certain witnesses: "I think it's generally looney toon people generally promoted this, women who look like soothsayers, and that sort of image I've associated with it. So I don't have any belief in it whatsoever" [emphasis added]. The honest but misguided were deemed not credible for other reasons; some were dismissed because they were "elderly people" or "small children" others were seen as being "too emotional" and thus subject to "placebo" type effects or autosuggestion. Mitch, for example, said: "I think strange things happen in this world and people tend to come up with the explanations that it was in their beliefs or their religious views, or their worldview, and that are consistent with it." Going on to illustrate with an example, he said: "I remember the case that physics department at Canterbury [University], they had a little study on the hospital maternity ward, where it was claimed that they had more babies during full moons. The matron there was absolutely convinced of it. So one of the students studied the records for the last 10 years and there were no data, couldn't find anything."

Likewise, an overactive imagination (with respect to, for example, ghosts haunting houses) was seen to be likely, with Nikki saying" "Ok he's heard some noise ... and he goes, I have certainly heard a ghost." Another reason for disbelieving personal testimony was that "people believe what they wish to believe," particularly in relation to religious matters (as evidenced in the haunted house proposition). Anne comments: "I think it has the potential to be tainted by the nature of the prior expectation of what they are going to see." Others saw friends and associates as less discerning about such experiences: "I had a couple of friends who used them [crystals to improve health] and they buy into that sort of stuff. But I have to say they tend to be very uncritical. They are not from a scientific background. I would take it with a grain of salt because they tend not to question."

In some cases the scientists dismissed other people's reported claims based on their own personal real-life experiences, feeling that many of their own personal experiences would have been interpreted by other perhaps more gullible - individuals as evidence for the propositions put before them in these studies. Hence, the testimony of others, when it conflicted with scientists' own more "logical" interpretations, resulted in the former being deemed unreliable by Charlie: "I personally would have experienced situations in a house where you think, oh that's a pretty scary noise and your imagination immediately starts to sort of think about those things. Yet when you sit down and rationalize it, you think, no, no. It's probably something like you know whatever happened here, the wind was banging on the door or whatever."

Credible witnesses were, perhaps not surprisingly, seen to be other scientists or "people educated with a science degree" according to Sue, and people whose "credibility is based on their record of having done 
some systematic research in a particular area" as identified by Miles. Others deemed credible included someone who was "doing a doctorate in engineering." Interestingly, the participants dismissed some claims on the basis of the evidence being anecdotal. However, anecdotal evidence from credible witnesses was deemed adequate - at least enough to question the likelihood of phenomena - or as adequate grounds for keeping an open mind. Mary comments: "Acupuncture has been practiced for thousands of years in China, so as I said it seems to be credible because it works in some individuals... But it's been used for thousands of years and in some people it has a dramatic effect."

Similarly, anecdotal evidence from "fairly stable sorts of people" was seen as a basis for thinking that some houses might be haunted, but was not seen as adequate for astrology-based claims because such anecdotes were likely tainted by reports from "charlatans" and "crackpots." Credible witnesses were thus seen to be level-headed people with no obvious ulterior motives, Brian pointing to "airline pilots have reported incidents of being followed by craft or things like that, I mean I would guess the majority of airline pilots are fairly sort of level headed people - we hope!"

Similar themes were seen for the religion and science study. A number of the scientists felt that whilst they themselves were not sure of the details of the evidence against some of the propositions, negative testimony from other scientists meant such propositions could not be taken seriously. This was most typically the case for the age of the Earth proposition with, for example, Keith a biologist commenting that "the scientific evidence of fossils and dinosaurs and all that sort of stuff, the age of the stars," and Jane another biologist saying "you would have to throw out so many theories to believe that one." This occurred irrespective of religious faiths with, for example, Annie, a Hindu, commenting "I know a little bit about carbon dating and I know it is definitely older than 10,000 years because I believe in the carbon dating technique and the research that has been done in terms of prehistoric creatures, and the evolution of man." When asked why she believed in carbon dating she replied, "because the half life of carbon-13 decays and produces isotopes of carbon, it has been scientifically proven, that decay kills off [sic] carbon."

Other participants pointed to things such as near death experiences for which in their minds, there were now sufficient reports to support the religious propositions presented in items about spirits/souls existing after death or returning in a subsequent life (Table 7). Alan comments: "Our consciousness is not affected by sleep or injury to the person's brain or whatever, there have been far too many cases of people remembering to dismiss...there are studies currently being conducted into near death experiences to the point where enough scientist are taking them seriously to warrant belief."

One scientist, an Earth scientist and fundamentalist Christian, ostensibly did think that the Earth was less than 10,000 years old. This he reasoned was a matter of data interpretation: "There is fossil and dating evidence, facts that suggests the Earth is millions of years old, these are facts...but you can interpret this in other ways." When questioned, he talked about a theory to do with changes in the speed of light which ostensibly meant that radio-chemical dating experiments were unreliable: "The speed of light is constant, but it may not always have been constant ... this would affect the reliability of the carbon-dating data."

\section{Theoretical Basis to Beliefs}

A strong theme to emerge was that the scientists though there might be some theoretical basis for the belief. This is not to say they knew of any such theoretical basis, but the scientists felt that some theoretical basis might be uncovered in the future. This differs markedly from notions of experiments or empirical testing (see below); rather it was seen as necessary for there to be "a possible mechanism of action." Teresa pointed out that "I could have a minimal number of observations, but if I could work out a possible explanation ok. It's like an Ouija board, if I could work out a possible explanation, then ok." Fiona shared this sentiment: "I think I would want to be convinced, I would want to know what people thought was actually happening, what they thought might be causing it." This she saw as essential for believing in propositions like those raised in the interviews: "I would find it a believable proposition in that it had an effect, but I would want to know why it had an effect, and I think because I don't know why, because I can't come up with an explanation why it may have an effect, then I suppose at the end of the day I would tend to think it's a psychological effect."

In the case of the proposition that crystals improve some people's health, some of the scientists could see a potential mechanism, based on their knowledge of crystals generally, and the fact that according to modern scientific theory, crystals can exert electrical or field effects. So Josie felt "there could possibly be some link between the chemical composition of the jewellery [and] absorbing something." Charlie expanded on this idea: "In my own mind there is a possibility that fields of whatever you like to call them, electricity or whatever there is associated with particular minerals, can potentially influence a force in the body." Likewise, the few that were less sceptical about astrology like Judy, thought that there were, potentially, underlying theoretical reasons not inconsistent with current scientific thinking: "There are physical aspects to the 
planets, the positions of the planets, so taking the physical and taking actual events that have happened to me, I just have to reserve judgement on that."

The scientists discriminated between fairly similar phenomena, with, for example, water divining seen as potentially credible, Terry saying "water diviners do work because the water in the pipe or whatever somehow works. There is an interaction between all objects," Teresa open to the idea "there appears to be something in it," and Josie suggesting that "You could rationalise that couldn't you? In terms of humidity differences in the desert or wherever." In contrast, finding a missing individual by swinging a pendulum over a map was not deemed credible: "I just can't see a connection between a map and a pendulum." So, because there was a potential theoretical reason in the former, namely "an interaction between all objects," water divining might work.

In some cases lack of belief was grounded in the individual's own scientific knowledge of a particular discipline. This, the scientist's felt, made them well qualified to judge the veracity of claims. So the physicists and Earth scientists were generally dismissive of astrological propositions confidently one asserting that "there is no evidence that the planets could affect you," and another saying "I think they are too far away to have any magnetic or electrical impact," and going on to relate this to their own scientific knowledge. Richard comments: "Knowing the affects, they are pretty minimal and I expect they would cancel out anyway ... Just because there's no scientific evidence, doesn't necessarily mean something is not true. But I would say that we understand pretty well the interaction between the planets and what's going on here, that we can almost completely rule out any possibility of an interaction." Others were equally dismissive of astrology on these grounds: "You are talking such vast distances and I really can't see that there could be any physical link." Similar expressions were made by chemists, within their area of expertise, for example, about the use of crystals to improve health: Brian comments: "I don't see you know the power of crystals so I don't see why something that's crystalline should have any magic effects just because it is crystalline ... I don't see what's special about quartz."

The lack of a theoretical basis to some beliefs was attributed to the socially-grounded nature of many of the beliefs discussed in interviews. This was particularly true in the case of numbers-based beliefs. Brian again: "If you go to somewhere like Japan, I think the number five, or the number seven, is unlucky and not the number 13." Nikki, likewise commented: "Unlucky? But in Russia it is the opposite." Similarly, beliefs about bad luck were seen to have social origins with Peter commenting: "This to me is one of those superstitions generated to control behaviour. Like a long time ago mirrors were extremely expensive to make."

Again similar themes emerged from the religion and science study. To illustrate, for most of these scientists human conception by spiritual rather than physical means was deemed impossible. Celia a Hindu, said: "It's ridiculous, it will never happen, I totally believe it is due to physical means, because I am not a Christian I have never tried too understand that." Similar views were expressed by Annie another Hindu: "Conception was like a gift that was handed to virgin mums, they were born into a normal family." However, some strong Christian adherents used their discipline-specific scientific knowledge to propose reasons as to why this might be possible. For example, human conception was seen as at least technically feasible since non-sexual reproduction in other species was well established as seen in Bill's comment: "It's a possibility that if we have an all loving God who constructed these processes in the first place using the natural things anyway, why can't you have as amictic cell [i.e., which can give rise to offspring without fertilization] in the ovary in the womb of a woman turn itself into an embryo? It happens in plants all the time." Those that discounted this proposition attributed the belief to something deemed to socially-acceptable at the time with, for example, Keith commenting "that way she [i.e., the mother of Christ] can't have been soiled in any way, something that has a basis in belief and trying to fit into a particular framework."

It was noteworthy that some scientist 're-worked' some of the items presented in the surveys, thinking on their feet and seeking alternative explanations. Alan, for example, as noted above was rather dismissive of Hindu beliefs in reincarnation, but upon probing he looked for alternative explanations that might be seen or interpreted as "evidence" at least consistent with such beliefs. He said of reincarnation"'the fact that genetic material is passed form one person to another as generations proceed, one after another, that is 'reincarnation' so to speak."

\section{Controlled Experiments and Appropriate Quantitative Evidence}

For some of the scientists controlled empirical experiments were seen to be able to - in principle at least - establish credibility of some of the propositions. Charlie, for instance, felt that "What I would look for would be some sort of correlation between when people were born and the positions of the stars and planets and what had actually happened to those people," in order to believe in astrology. Mary likewise felt that "some statistical analysis of how it all matched, horoscopes of people that have now died, look at what has happened and see if it matches," might convince her. 


\section{Simple Alternative Explanations}

Even reliable empirical evidence, or highly credible testimonies, were seen to be unconvincing in some cases. As mentioned above, the scientists felt that there would need to be a reasonable explanation even in the light of overwhelming empirical support. The participants felt that for such 'evidence' there would likely be other more credible - or equally credible explanations. Fiona, for example, said that reports of crystals improving health "may have happened because of some other factor." Explanations must be "complete," they must explain regularity of events, and be able to offer explanations for those circumstances in which the event differs. In other words, anecdotal or other evidence in support of beliefs (superstitious or otherwise) could also be dismissed on the basis of coincidence. Terry comments: "I have a lot of trouble believing that it was anything to do with the breaking of a mirror. There would be a second order of explanation that could be used, and even with evidence I don't believe it could be true."

Countering coincidence is seen thus to be important, this was raised in a number of interviews when the scientists commented about the use of clairvoyants in police investigations and soothsayers like Nostradamus. Anne comments about a local police investigation in which the police (unsuccessfully) employed a psychic to try to find the body of a murdered child. "You don't have the prediction in the discovery, you have discovery in the prediction ... you hear that sort of thing it will be like you know Nostradamus predicted the state of the World. Some of the psychic cases I've been involved with like Mona Blades [a famous New Zealand murder victim], it was sort of like make the prediction. I mean some cases where they've claimed to have had a positive hit it tends to have been that they claimed to make predictions but no one's recorded, before the event took place."

\section{We Don't Know Enough}

For a number of propositions the scientists felt that they could not completely discount a given proposition because the knowledge of science in this area is tenuous or incomplete (in the minds of these participants at least). As a consequence, alternative explanations must be considered, or at least cannot be totally discounted. These scientists were thus surprisingly open-minded about some beliefs. Nigel, for instance, said "I think in time we will find life somewhere else out there," and cosmic and religious related beliefs (e.g. ghosts and aliens) were those most widely believed. Peter, for example, stated: "I can't absolutely say that there is no possible effect of the way the cosmos works at particular times - we don't know enough about physics at the moment to say that that it has effects." This, it seems, came from a belief that we don't know enough about such events - in the minds of these scientists suggesting we need to keep our options open. Charlie, for example, said: "I think it is possible that aliens in whatever form might have landed on Earth in the past and left no evidence of their arrival ... In my mind we have detected nothing, and we as a society have not been able to travel far in space to try and go further than our ability to communicate." Other arguments related to the nature of aliens, as Josie pointed out "it depends on what you mean by alien doesn't it? Whether or not they are viral particles or bacterial particles whatever they might be."

Probability arguments based on the sheer numbers of space objects seemed to sway some of the scientists. Jane for example, felt "If you are defining all the conditions of planets you need to sustain life in terms of what a planet can have, not being too cold, right sort of atmosphere, a sun that lives long enough for life to actually happen, then there's millions and millions of planets out there and the laws of probability at least one of them is going to have life."

Others also related their ideas to the "Roswell incident" and other cosmic matters and seemed influenced by the astronomical space-time context, with, for example, Mitch saying, "there could be life forms out there in the universe, possibility that there is life on a number of those planets. [There is] the possibility that intelligent life has evolved quicker than it did on Earth and therefore may have visited the Earth."

The comparative paucity of knowledge about astronomical and historical phenomena and events was also seen as grounds for keeping one's options open. It thus seems that the scientists were aware of historical paradigm shifts in scientific thinking and this influenced them to keep an open mind. Mitch comments: "I think you've got to think outside the box when it comes to anything ... you still can't let yourself be too closed in by their interpretations that if someone's offered an alternative one and it's credible from a scientific point of view then you should let your mind open a little bit."

Such thinking also applied to the scientists' perceptions of our understanding of the brain, with many of the scientists thinking that there remains much unexplained about the brain - thus they were open to alternative explanations including paranormal phenomena. Brian comments: "We're only getting to grips with sort of the medical side of our bodies and how you fix tonsillitis and appendicitis and things like that and we don't really know how the brain works and whether, some people have other abilities and that kind of thing."

Other geographical and physically anomalous phenomena were seen as difficult to explain; such as lines in South American deserts. Mary's comments: 
"The Nasca Lines in Peru. Where the symbols can only be seen from the air yet from the dating of them they were made far before anybody had a sort of means of flying as far as we know ... Obviously that may not be the only explanation, but I think it is one possible explanation." Historical matters commonly surfaced as seen in, for example, Thomas's comments on Stonehenge and the like: "I guess I read about these things where certain inventions are turned up in Egyptian times like batteries and things and it makes you wonder. Stonehenge, how could they have conceived that, being the primitive peoples they were back then? It makes you wonder."”

The notion that we simply don't know enough about many "spiritual things" meant that some of the participants in the religion and science study likewise felt that "we need to keep an open mind." This particularly occurred in relation to ephemeral things such as spirits and souls living on after physical death and cosmological notions of pre-determinism and order in the universe or its creatures. Mary indicated that she thought that order in the universe was almost certainly due to a higher spiritual power: "You're looking at some structure, let's say a fly or a spider, now what are the chances the probability that something like that can construct itself?" This was universal across the religious denominations with Annie a Hindu commenting that the reason she was prepared to believe the notion that after death a spirit could continue to exist was because "I think that there is a lot yet to be discovered, there's a lot yet unknown that we don't know about and it could be proven...even if science has not proved it now, who know what might happen in the next 1000 years?" She held similar views about people being cured by petition to a higher power: "People diagnosed with cancer found other ways and means not in terms of cures like alterative medicines, but in terms of believing, having faith and praying or taking up religion that they have been healed," although she went on to comment that this was likely due to "a belief that they can destroy it if people believe in something it gives them the ability to fight something better."

\section{Scientist Habits of Mind}

Our argument here is that developing an understanding of actual scientists' views about evidence and rationale of evidence claims provides insights into their habits of mind (as defined by Gauld, 2005). These habits of mind appeared to be a consequence of both personal beliefs arising from a variety of experiences, including their scientific training. It is likely that the formation of these habits of mind also was influenced by a variety of factors such as upbringing and environmental-cultural influences. However, the data here suggest personal beliefs and scientific training together exert a potent influence in the formation of scientists' habits of mind. The most significant outcome for this interesting mixture of scientists is variation in habits of mind: for example, for some participants personal beliefs (including religious beliefs) appear to override their scientific training and the norms of their profession; for others personal beliefs are paramount; and, for some personal beliefs and scientific thinking are compartmentalized. Here we seek to identify what we see as the main habits of mind that are evident from our findings.

First, is a combination of the habits of mind, rationality and skepticism. Evidence for this comes from beliefs of the capacity of petition to a higher power to cure illness - or not - depending on the dominance of science or religion; to make life or career choices based on religious beliefs; and, to modify our physical environment or environmental management practices because both science and religion encourage this. These scientists thus appear to engage in a toss up between rationality and skepticism when dealing with the issues mentioned above.

Second, is a combination of the habits of mind open-mindedness, rationality and mistrust of arguments from authority. Evidence here comes from the view that scientists need to be open to alternative interpretations even if these are outside mainstream science, including major theoretical paradigms like evolution, or seemingly unchallengeable things like human conception. So here the scientists are openminded, do not automatically accept the prevailing view, but seek to rationalize the evidence in front of them.

Third, and related to that mentioned above, is the habit of mind open-mindedness. Evidence here comes from a view that because of a consciousness of alternative interpretations for say religious and scientific ideas, teachers of tertiary level science need to be aware of the potential religious diversity in their classes, and teach in a manner that is respectful of personal religious views, whilst maintaining scientific integrity. This necessitates an open-minded outlook to science than many may instinctively think was absent in science learning environments.

\section{IMPLICATIONS FOR SCIENCE TEACHING AND LEARNING}

Some authors have argued that an outcome of good science education is improvement in scientific and technological literacy (Laugksch, 2000; Mahner \& Bunge, 1996a, 1996b) and argue that religion and superstition are 'antiscience (see, Matthews, 1996, \& references therein). Modern citizens constantly confront scientific and technological issues and science/religious conflicts. Given that scientists are generally seen as (sometimes 'tainted') authority figures 
with respect to science claims, it is of interest for science educators to understand what beliefs scientists hold, and on what basis, they hold such beliefs. A more liberal approach to science teaching might, as Matthews (1996) posits, "maintain that science instruction should be more than merely the conveyance of factual knowledge" (p. 91). Quite so. In other words, science is value-laden as many authors working in the area of the nature of science have long maintained (see, e.g., Sutching, 1995). Others like Ogawa (2002) argue that science needs to move beyond the Western view of science and take cognisance of "indigenous science."

One feature of scientific literacy is the ability to make credibility judgements of peoples' and scientists' testimony. Scientific literacy is important in modern society as people encounter debates and issues of a scientific and technological nature, including science curriculum matters. This study provides a window into some scientists' thinking, in this case with respect to potential conflicts between science and religion. The research findings provide evidence for dissonance for many of these participants, but others have in contrast rationalized such dissonance in variety of ways. It is our view that these data point to a more open-minded attitude than is commonly ascribed to scientists. This suggests that scientists are not automatically dismissive of non-scientific beliefs (including religious beliefs) and points to a human dimension of scientific thinking.

A second issue is the impact if any of scientists' beliefs on their teaching of scientific content, especially in the case of religious beliefs that conflict with science theories. A scientist's research is screened in that if he or she wishes to publish research in scientific journals peer-review likely 'screens out' views that are widely disparate from those held consensually by the particular community, such as chemists, Earth scientists, and so on (insofar as there is consensual agreement). The fact that many of the scientists in the present work held beliefs that were in direct conflict with 'normal science' is not necessarily of concern in this context. Tertiary level teachers arguably have more autonomy over specific course content (in that, for example, they are not constrained by external curricula) although course offerings may be subject to some peer review and scrutiny (e.g., accreditation programs exist for many professions, and course structure and content in tertiary level science are often externally moderated, especially at advanced levels). But what of say an Earth scientist or biologist that is required to teach current scientific theories that conflict with their personal religious beliefs? Several such individuals were identified in this work. There are several possible explanations or responses to such an issue. First, many religious beliefs (spirits, destiny, special status of animals, etc.) are topics unlikely to arise during teaching (McGeorge, 1992, points out that in the school system sometimes this also is avoided when the topic evolution is not expressing presented in curriculum documents). Second, such individuals might seek to avoid occupations, including tertiary level teaching, that result in such encounters.

Mahner and Bunge (1996a) assert that "consistency in one's belief system is hard to come by" (p. 112). This seems to be borne out in the present work. However, their addendum that this is "particularly [so] in the midst of a society where religion wields a formidable cultural and political power," seems to us to be somewhat overstating the case.

\section{REFERENCES}

Allchin, D. (1998). Values in science and science education. In B.J. Fraser \& K.G. Tobin (Eds.), International handbook of science education (pp. 1083-1092). Dordrecht: Kluwer.

Ben-Ari, M. (2005). Situated learning in 'this high-technology world'. Science \& Education, 14, 367-376.

Brunton, M., \& Coll, R.K. (2005). Enhancing technology education by forming links with industry: A New Zealand case study. International Journal of Science and Mathematics Education, 3, 141-166.

Cameron, C., Moss, P., \& Owen, C. (1999). Men in the nursery: Gender and caring work. London: Paul Chapman:

Carson, R.N. (1998). Science and the ideals of liberal education. In B.J. Fraser \& K.G. Tobin (Eds.), International handbook of science education (pp. 1001-1014). Dordrecht: Kluwer.

Center for Drug Evaluation and Research (2002). Thalidomide. Retrieved 22 August 2005 from http://cerhr.niehs.nih. gov/genpub/topics/thalidomide2-ccae.html

Chalmers, A.F. (1999). What is this thing called science? St. Lucia, Queensland: Queensland University Press.

Coll, R.K., \& Taylor, N. (2004). Probing scientists' beliefs: How open-minded are modern scientists? International Journal of Science Education, 26(6), 757-778.

Dagher, Z., \& BouJaoude, S. (1997). Scientific views and religious beliefs of college students: The case of biological evolution. Journal of Research in Science Teaching, 34(5), 429-445.

Dagher, Z.R., \& Ford, D.J. (2005). How are scientists portrayed in children's science biographies? Science \& Education, 14, 377-393.

Dalgety, J., Zegwaard, K.E., McCurdy, S., \& Coll, R.K. (September, 2003). Situated learning in cooperative education workplacements as an agent of enculturation into science academia: Preliminary findings. Paper presented at the British Educational Research Association Annual Conference. Edinburgh, United Kingdom.

Durei, A. (1997). Technology and Maori. In J. Burns (Ed.), Technology in the New Zealand curriculum (pp. 31-45). Palmerston North, New Zealand: Dunmore.

Evans, K., \& Heidegger, G. (July, 1999). Situated learning and 'Re-integration Initiatives' for young people: Policies and practices. Roundtable discussion at the European Conference on Educational Research, Lahti, Finland. 
Gauld, C.F. (1982). The scientific attitude and science education: A critical reappraisal. Science Education, 66, 109-121.

Gauld, C.F. (2005). Habits of mind, scholarship and decision making in science and religion. Science \& Education, 14, 291-308.

Gauld, C.F., \& Hukins, A.A. (1980). Scientific attitudes: A review. Studies in Science Education, 7, 129-161.

Good, R.G., Wandersee, J.H., \& St Julien, J. (1993). Cautionary notes on the appeal of the new 'ism' (constructivism) in science education. In K. Tobin (Ed.), The practice of constructivism in science education (pp. 71-87). Hillsdale, NJ: Lawrence Erlbaum.

Gould, S.J. (1983). Evolution as fact and theory. In Hen's teeth and horse's toes (pp. 253-262). New York: Academic Press.

Gould, S.J. (1991a). Genesis and geology. In Bully for brontosaurus (pp. 402-415). New York: Norton.

Gould, S.J. (1991b). Justice Scalia's misunderstanding. In Bully for brontosaurus (pp. 448-460). New York Norton.

Greenfield, B. (2000). SET Fair: A report on women in science, engineering and technology. London: Department for Trade and Industry.

Guba, E.G., \& Lincoln, Y.S. (1989). Fourth generation evaluation. Newbury Park, CA: Sage Publication.

Guisasola, J., Almudíl.M., \& Furió, C. (2005). The nature of science and its implications for physics textbooks. Science \& Education, 14, 321-338.

Herron, M.D. (1969). Nature of science: Panacea or Pandora's Box? Journal of Research in Science Teaching, 6, 105-107.

Johnson, P., \& Gott, R. (1996). Constructivism and evidence from children's ideas. Science Education, 80(5), 561-577.

Jayarata, T.E., Thomas, N.G., Trautmann, M. (2003). Intervention program to keep girls in the science pipeline: Outcome differences by ethnic status. Journal of Research in Science Teaching, 40(4), 393-414.

Jegede, O., \& Okebukola, P.A. (1989). Some socio-cultural factors militating against the drift towards science and technology in secondary schools. Research in Science and Technology Education, 7(8), 141-151.

Jegede, O.J., \& Okebukola, P. A. (1991). The relationship between African traditional cosmology and students' acquisition of a science process skill. International Journal of Science Education, 13(1), 37-47.

Kahle, J.B, \& Lakes, M.K. (1983). The myth of equality in science classrooms, Journal of Research in Science Teaching, 40(supplement), S58-S67. - Reprinted 2003.

Kass, L. (1988). Evolution and the Bible: Genesis I revisited. Commentary, 86(5), 29-39.Guisasola, J. Almudí, \& Furió, C. (2005). The nature of science and its implications for physics textbooks. Science \& Education, 14, 321-338.

Laugksch, R.C. (2000). Scientific literacy: A conceptual overview. Science Education, 84, 71-94.

Lave, J., \& Wenger, E. (1991). Situated learning: Legitimate peripheral participation. New York: Cambridge.

Mahner, M., \& Bunge, M. (1996a). Is religious education compatible with science education? Science \& Education, 5(2), 101-123.
Mahner, M., \& Bunge, M. (1996b). The incompatibility of science and religion sustained: A reply to our critics. Science \& Education, 5(2), 189-199.

Marton F., \& Booth, S. (1997). Learning and awareness. Mahwah, NJ: Lawrence Erlbaum.

Matthews, M.R.(1996). Editorial. Science \& Education, 5, 91-99.

Matthews, M.R.(1998). The nature of science and science teaching. In B.J. Fraser \& K.G. Tobin (Eds.), International handbook of science education (pp. 981-999). Dordrecht: Kluwer.

McGeorge, C. (1992). Evolution and the New Zealand primary school curriculum 1900-1950. History of Education, 21(2), 205-218.

Merriam, S.B. (1988). Case study research in education. San Francisco: Jossey-Bass.

Nestle, M. (2003). Safe food. Berkley, CA: University of California Press.

Ogawa, M. (2002, July). Nature of indigenous science: A stratified and amalgamated model of knowledge and cosmology. Paper presented at the annual meeting of the Australasian Science Education Research Association. Townsville, Australia.

Paku, L., Coll, R.K. (2005, July). Workplace enculturation: Science and technology work placements as agents of enculturation for indigenous peoples. Paper presented at the 14th World Conference on Cooperative Education. Boston, MA..

Peshkin, A. (1993). The goodness of qualitative research. Educational Researcher, 22(2), 24-30.

Pfundt, H., Duit, R. (2000). Bibliography: Student's alternative frameworks and science education (5th edn.). Kiel, Germany: University of Kiel.

Poole, M. (1996). ' '...for more and better religious education'. Science and Education, 5, 165-174.

Preece, F.W., \& Baxter, J. H. (2000). Scepticism and gullibility: The superstitious and pseudo-scientific beliefs of secondary school students. International Journal of Science Education, 22(11), 1147-1156.

Reif, F. (1995). Understanding and teaching important scientific thought processes. Journal of Science Education and Technology, 4(4), 261-282.

Reiss, M.J. (2003). Science education for social justice. In C. Vincent (Ed.) Social justice, education and identity (pp. 153165). London: Routledge Falmer.

Sade, D., \& Coll, R.K. (2003). Solomon Island stakeholders' views of technology and technology education. International Journal of Science and Mathematics Education, 1, 87-114.

Sutching, W.A. (1994). Notes on the cultural significance of the sciences. Science and Education, 3, 1-56.

Taylor, N., Nathan, S., \& Coll, R. (2004). Education for sustainability in regional New South Wales, Australia: An exploratory study of some teachers' perceptions. International Research in Geographical and Environmental Education, 12(4), 289-309.

Tobin, K., \& Tippins, D. (1993). Constructivism: A paradigm for the practice of science education. In K. Tobin (Ed.), The practice of constructivism in science education (pp. 3-21). Hillsdale, NJ: Lawrence Erlbaum Associates.

Turner, P. (1995). An overview of feminist perspectives as they relate to science and mathematics education. The Mathematics Education, 6(1), 3-7. 
Woolnough, B.E. (1996). On the fruitful compatibility of religious education and science. Science and Education, 5, 175-183.

Wretsch, J.V. (1991) Voices of the mind: A sociocultural approach to mediated action. Cambridge, MA: Harvard University Press.

Yates, G.C.R., \& Chandler, M. (2000). Where have all the sceptics gone? Patterns of new age beliefs and antiscientific attitudes in preservice primary teachers. Research in Science Education, 30(4), 377-397.

Zinman, J. (1968). Public knowledge. London: Cambridge University Press

\section{$\diamond \diamond \diamond$}

